\title{
Short communication: Use of young bulls in the United States
}

\author{
J. L. Hutchison, ${ }^{1}$ J. B. Cole, and D. M. Bickhart \\ Animal Improvement Programs Laboratory, Agricultural Research Service, USDA, Beltsville, MD 20705-2350
}

\begin{abstract}
The availability of genomic evaluations since 2008 has resulted in many changes to dairy cattle breeding programs. One such change has been the increased contribution of young bulls ( 0.8 to $3.9 \mathrm{yr}$ old) to those programs. The increased use of young bulls was investigated using pedigree data and breeding records obtained from the US national dairy database (Beltsville, $\mathrm{MD})$. The adoption of genotyping was so rapid that by $2009,>90 \%$ of all Holstein artificial insemination (AI) service sires and $86 \%$ of Jersey AI service sires were genotyped, regardless of age. The percentage of sons sired by young bulls increased by 49 percentage points (10\% in 2008 compared with $59 \%$ in 2012 ) due to the onset of genomic evaluations for Holsteins and by 46 percentage points for Jerseys (11 and 57\%, respectively). When limiting these data to sons retained for breeding purposes through AI, the increase was even more dramatic, increasing approximately 80 percentage points from 2008 to 2012 for both Holsteins and Jerseys (1, 5, 28, 52, and $81 \%$ for Holsteins and 3, 4, 43, 46, and $82 \%$ for Jerseys from 2008 through 2012). From US breeding records from 2007 through 2012, 24,580,793 Holstein and 1,494,095 Jersey breedings were examined. Young bulls accounted for $28 \%$ and $25 \%$ of Holstein and Jersey breedings in 2007, respectively. These percentages increased to $51 \%$ of Holstein and $52 \%$ of Jersey breedings in 2012, representing 23- and 27-percentage-unit increases, respectively. Matings to genotyped young bulls have rapidly increased while the use of nongenotyped bulls has diminished since the onset of genomics. Mean sire age for Holstein male progeny born in 2012 was 2.7 yr younger than males born in 2006, and 1.3 yr younger for females; corresponding values for Jerseys were 2.3 and $0.9 \mathrm{yr}$. Holstein male offspring had an increase of $281 \mathrm{~kg}$ between 2006 and 2012, compared with $197 \mathrm{~kg}$ between 2000 and 2006 for parent averages (PA) for milk, an increase of $84 \mathrm{~kg}$ between the 2 periods. Jersey male offspring had an increase of $49 \mathrm{~kg}$ between the 2 periods. To demonstrate the economic impact of the
\end{abstract}

Received September 25, 2013.

Accepted January 8, 2014.

${ }^{1}$ Corresponding author: Jana.Hutchison@ars.usda.gov differential use of young bulls, herds were grouped by the frequency of their use of young bulls, and average PTA for milk and net merit for cows that were bred in 2003 through 2012 were calculated. In 2012, herds using $>75 \%$ young bulls created offspring that had a PA of $+52 \mathrm{~kg}$ for milk and $+\$ 58$ net merit compared with herds using no young bulls. Jersey herds using $>75 \%$ young bulls created offspring that had a PA of $+142 \mathrm{~kg}$ for milk and $+\$ 63$ for net merit compared with herds using no young bulls. Use of young bulls has greatly reduced the generation interval and improved the rate of genetic gain since the implementation of genomic evaluations.

Key words: young bull, breeding, genomics

\section{Short Communication}

The implementation of genomic evaluations in 2008 has revolutionized dairy cattle breeding by greatly increasing the accuracy of genetic predictions for young animals. Genomic evaluations use information from genotypes that are extensively checked for call quality and parental conflicts (Wiggans et al., 2011), although their accuracy is highly dependent on the number of animals that are in the predictor population. All young bulls purchased by major AI organizations now are selected based on genomic evaluations, which allows breeders to identify genetically superior animals at a much younger age (Schefers and Weigel, 2012). In fact, bulls that have been genotyped can be evaluated for superior traits before they reach sexual maturity rather than waiting for evaluations on their resultant progeny. This greatly reduces the time and cost to identify bulls that are genetically superior. The use of young bulls (bulls $<4$ yr old when their semen was used) was investigated by looking at the percentage of young bulls genotyped and the percentage of young bulls used in US breeding records. Generation intervals and herd usage of young bulls were also examined to determine if a higher rate of genetic gain was achieved by using young bulls.

Pedigree data and breeding records were obtained from the US national dairy database (Beltsville, MD). In total, 24,580,793 Holstein and 1,494,095 Jersey breeding records were distributed among17,519 Holstein and 
4,044 Jersey herds. The age of service sires from those records was categorized into 3 groups: young bulls ( 0.8 to $3.9 \mathrm{yr}$ ), first-crop sires (4.0 to $7.9 \mathrm{yr}$ ), and older sires $(\geq 8.0 \mathrm{yr})$, as in Olson et al. (2011).

\section{Rapid Adoption of Genotyping and Young Bull Predictions}

Genotyping provides the opportunity to screen thousands of candidate young sires for AI service by selecting the best possible candidate bulls. Accurate genomic predictions have allowed breeders to identify genetically superior animals at a much younger age, both male and female. The adoption of genotyping was so rapid that by $2009,>90 \%$ of Holstein AI service sires and $86 \%$ of Jersey AI service sires were genotyped, regardless of the age of the bull. Currently, 100\% of Holstein and Jersey young AI bulls are genotyped. Several factors contributed to this rapid adoption, including an economic benefit, an earlier accurate prediction for young bulls, and an increase in prediction reliabilities.

Earlier predictions allow young bulls to be used as sires of sons at a higher percentage than they were previously. To investigate this, the percentage of sons sired by young bulls was examined. On average, 31,777 Holstein sons were born each year from 2008 through 2012, with 31,394 sons born in 2008 and 32,310 born in 2012. An increasing number of progeny were sired by young bulls in these years with $3,205,3,039,6,596$, 10,618 , and 19,026 sons sired by young bulls in 2008, 2009, 2010, 2011, and 2012, respectively. The numbers of Jersey sons sired by young bulls were $322,392,831$, 1,101 , and 1,942 for the same years, out of an average of 3,242 Jersey sons born for each of those 5 yr $(2,836$ and 3,431 sons born in 2008 and 2012, respectively). The percentage of all sons sired by young bulls increased by 49 percentage points ( $10 \%$ in 2008 compared with $59 \%$ in 2012) due to the onset of genomic evaluations for Holsteins and by 46 percentage points for Jerseys (11 and 57\%, respectively), as shown in Table 1.

When limiting these data to sons retained for breeding purposes through AI, 12, 94, 578, 912, and 869

Table 1. Percentage of Holstein and Jersey sons sired by young bulls (ages: 0.8 to 3.9 yr) by birth year of all sons and sons retained for breeding purposes through AI

\begin{tabular}{lccccc}
\hline & \multicolumn{2}{c}{ Holstein } & & \multicolumn{2}{c}{ Jersey } \\
\cline { 2 - 3 } \cline { 5 - 6 } $\begin{array}{l}\text { Birth year } \\
\text { of sons }\end{array}$ & All sons & AI sons & & All sons & AI sons \\
\hline 2008 & 10 & 1 & & 11 & 3 \\
2009 & 10 & 5 & & 13 & 4 \\
2010 & 20 & 28 & & 25 & 43 \\
2011 & 35 & 52 & & 32 & 46 \\
2012 & 59 & 81 & & 57 & 82 \\
\hline
\end{tabular}

Holsteins sons were sired by young bulls born in 2008 through 2012, with 1,625, 1,764, 2,072, 1,749, and 1,067 total Holstein bulls sampled over the same period.

For Jersey sons, 7, 8, 125, 99, and 137 were sired by young bulls and 202, 206, 289, 216, and 168 were sampled. Therefore, the percentage of AI sons sired by young bulls was $1,5,28,52$, and $81 \%$ for Holsteins and $3,4,43,46$, and $82 \%$ for Jerseys (Table 1), which approximately equates to an 80-percentage-point increase from 2008 to 2012 for both Holsteins and Jerseys.

\section{Young Bulls as Service Sires}

One of the implications of the accuracy of genomic predictions is that more young bulls could be used in US selection programs. We investigated the adoption of young bulls as service sires by analyzing the percentage of inseminations by breeding year, service sire age, and genotyped status for breeding records of Holstein and Jersey bulls (Table 2). Age of service sires was categorized into the same 3 groups as before: young ( 0.8 to $3.9 \mathrm{yr}$ ), first-crop (4.0 to $7.9 \mathrm{yr}$ ), and old ( $\geq 8.0 \mathrm{yr}$ ). We observed increased use of young bulls (regardless of genotyped status) between 2007 and 2012 for Holstein and Jersey. Young bulls accounted for 28 and $25 \%$ of Holstein and Jersey breedings in 2007, respectively. These percentages increased to $51 \%$ of Holstein and $52 \%$ of Jersey breedings in 2012, representing 23- and 27-percentage-unit increases, respectively. Genotyped young bulls accounted for $0,26,92,98,99$, and $100 \%$ of breedings of young Holstein bulls annually from 2007 through 2012; corresponding percentages for Jersey young bulls were $0,<1,72,98,99$, and $100 \%$. This means that in 2007 and 2008, a large proportion of young Holstein and Jersey bulls were used in matings before being genotyped. Matings to nongenotyped sires, regardless of age, have diminished since the onset of genomics, decreasing from 28,54, and $15 \%$ in 2007 for young, first-crop, and old Holstein sires and 25, 55, and $18 \%$ for Jersey sires to $\leq 1 \%$ in 2012 for all age groups and breeds (Table 2). First-crop sire usage, regardless of genotype status, decreased for Holstein matings by 16 percentage units (from 56\% in 2007 to $40 \%$ in 2013) and for Jersey matings by 17 percentage units (from $55 \%$ in 2007 to $38 \%$ in 2013). Matings to genotyped young bulls have rapidly increased and the use of nongenotyped bulls has waned since the onset of genomics.

\section{Generation Interval}

The shift from the time-consuming method of progeny testing to genomic predictions of young bulls has greatly reduced the generation interval in the dairy cattle breeding programs that use genotyped young 
Table 2. Percentages of bulls at service sire age ${ }^{1}$ and genotyped status by breeding year in US Holstein and Jersey breeding programs

\begin{tabular}{|c|c|c|c|c|c|c|}
\hline $\begin{array}{l}\text { Breed and } \\
\text { breeding year }\end{array}$ & $\begin{array}{l}\text { Young, } \\
\text { genotyped }\end{array}$ & $\begin{array}{c}\text { Young, } \\
\text { nongenotyped }\end{array}$ & $\begin{array}{l}\text { First crop, } \\
\text { genotyped }\end{array}$ & $\begin{array}{c}\text { First crop, } \\
\text { nongenotyped }\end{array}$ & $\begin{array}{c}\text { Old, } \\
\text { genotyped }\end{array}$ & $\begin{array}{c}\text { Old, } \\
\text { nongenotyped }\end{array}$ \\
\hline \multicolumn{7}{|l|}{ Holstein } \\
\hline 2007 & 0 & 28 & 2 & 54 & 1 & 15 \\
\hline 2008 & 8 & 22 & 23 & 29 & 11 & 7 \\
\hline 2009 & 36 & 3 & 40 & 4 & 15 & 2 \\
\hline 2010 & 42 & 1 & 39 & 3 & 13 & 2 \\
\hline 2011 & 48 & 0 & 39 & 1 & 11 & 1 \\
\hline 2012 & 51 & 0 & 40 & 0 & 8 & 1 \\
\hline \multicolumn{7}{|l|}{ Jersey } \\
\hline 2007 & 0 & 25 & 0 & 55 & 2 & 18 \\
\hline 2008 & 0 & 26 & 18 & 32 & 12 & 12 \\
\hline 2009 & 22 & 9 & 44 & 6 & 19 & 0 \\
\hline 2010 & 32 & 1 & 49 & 3 & 15 & 0 \\
\hline 2011 & 42 & 1 & 46 & 1 & 10 & 0 \\
\hline 2012 & 52 & 0 & 37 & 1 & 10 & 0 \\
\hline
\end{tabular}

${ }^{1}$ Age of service sire was categorized into 3 groups: young bulls (0.8 to $3.9 \mathrm{yr}$ ), first-crop sires (4.0 to $\left.7.9 \mathrm{yr}\right)$, and older sires $(\geq 8.0 \mathrm{yr})$.

bulls. The ages of the parents for male and female Holstein and Jersey offspring born in 2000, 2006, and 2012 were examined (Table 3). As expected, we observed very little to no change in the age of sires for offspring (both male and female) born in 2000 and 2006. In contrast, sires for Holstein males born in 2012 were $2.7 \mathrm{yr}$ younger than males born in 2006, and $2.3 \mathrm{yr}$ younger for Jersey males during the same time interval. The sires of Holstein females born in 2012 were $1.3 \mathrm{yr}$ younger than females born in 2006, and 0.9 yr younger for Jersey females. Results were similar to Norman et al. (2012), who found the mean sire age for Holstein progeny born in 2011 to be 23 mo younger than in 2006 for males and 12 mo younger for females; corresponding values for Jerseys were 15 and 4 mo.

The ages of dams also showed little or no change between 2000 and 2006, with slight decreases between 2006 and 2012. Dams were 0.7 and 0.3 yr younger for Holstein and Jersey male offspring born in 2012 compared with 2006, most likely due to the selection of females for use as bull dams at a younger age. Dams were 0.2 and 0.5 yr younger for Holstein and Jersey female offspring born in the same time interval. One reason for this decline is the decrease in age at first calving reported by Cole et al. (2013), who found a negative genetic trend from 1970 to 2007. An increase in beef prices could also be responsible for this high turnover rate (USDA-NASS, 2013).

To quantify the benefit of the decrease in generation interval between 2006 and 2012, parent averages (PA) for milk and net merit were calculated using values derived from the genetic evaluations from December 2012 for male and female offspring born in 2000, 2006, and 2012. The total genetic gain of milk yield for Holstein male offspring (Figure 1) between 2000 and 2006 was $197 \mathrm{~kg}$, compared with $281 \mathrm{~kg}$ between 2006 and 2012, an increase of $84 \mathrm{~kg}$ between the 2 periods. For net merit, the difference was $\$ 163$ and $\$ 329$, an increase of $\$ 166$. For Jersey male offspring, the results were similar to those of Holsteins, with an increase of $49 \mathrm{~kg}$ of milk and $\$ 85$ for net merit between the 2 periods.

The total genetic gain for Holstein and Jersey female offspring (Figure 1) was not nearly as great as that for male offspring but still showed some increase in gain

Table 3. Generation intervals for male and female Holstein and Jersey offspring born in 2000, 2006, and 2012

\begin{tabular}{|c|c|c|c|c|c|c|}
\hline \multirow{3}{*}{$\begin{array}{l}\text { Sex of offspring } \\
\text { and birth year }\end{array}$} & \multicolumn{3}{|c|}{ Holstein } & \multicolumn{3}{|c|}{ Jersey } \\
\hline & \multicolumn{2}{|c|}{ Average age (yr) } & \multirow{2}{*}{$\begin{array}{c}\text { Progeny } \\
\text { (no.) }\end{array}$} & \multicolumn{2}{|c|}{ Average age (yr) } & \multirow{2}{*}{$\begin{array}{c}\text { Progeny } \\
\text { (no.) }\end{array}$} \\
\hline & Sire & Dam & & Sire & Dam & \\
\hline \multicolumn{7}{|l|}{ Males } \\
\hline 2000 & 7.1 & 4.6 & 37,713 & 7.0 & 4.9 & 3,047 \\
\hline 2006 & 7.1 & 4.5 & 36,097 & 7.0 & 4.9 & 3,802 \\
\hline 2012 & 4.4 & 3.8 & 33,848 & 4.7 & 4.6 & 3,692 \\
\hline \multicolumn{7}{|l|}{ Females } \\
\hline 2000 & 6.7 & 4.0 & 586,994 & 6.3 & 4.2 & 56,962 \\
\hline 2006 & 6.8 & 3.8 & 706,067 & 6.3 & 4.0 & 70,824 \\
\hline 2012 & 5.5 & 3.6 & 766,335 & 5.4 & 3.5 & 101,781 \\
\hline
\end{tabular}


(a)

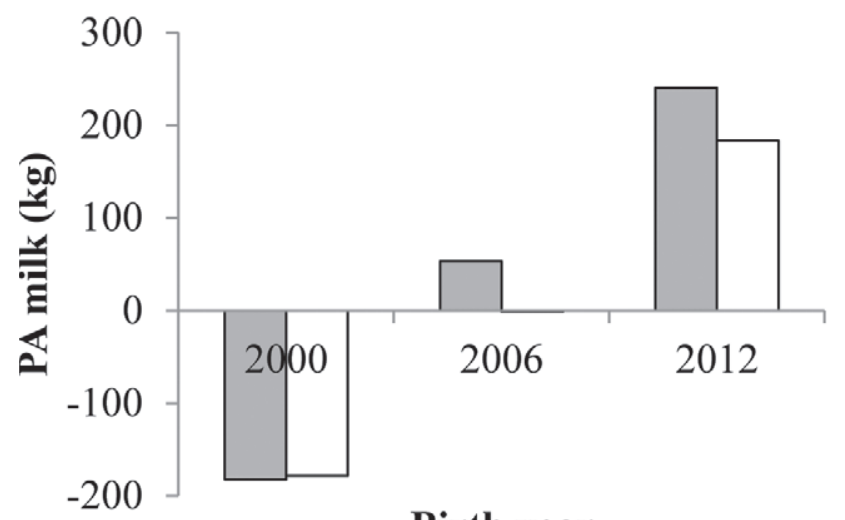

Birth year

(b)

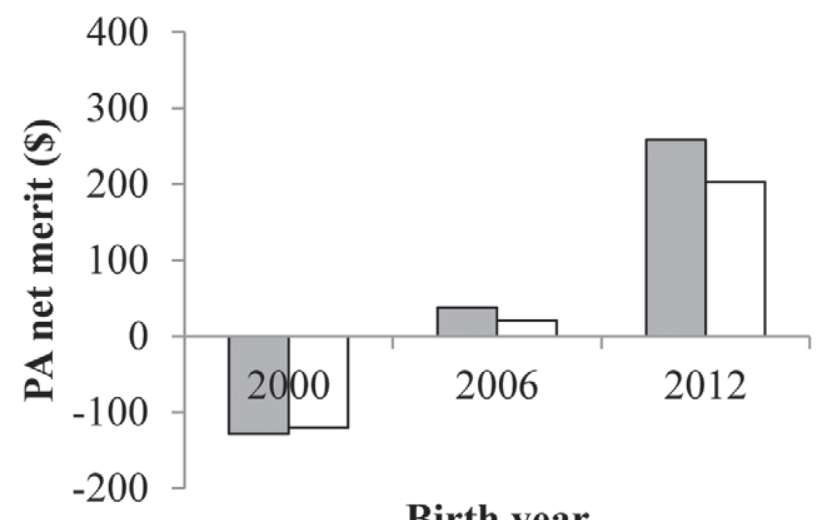

(c)

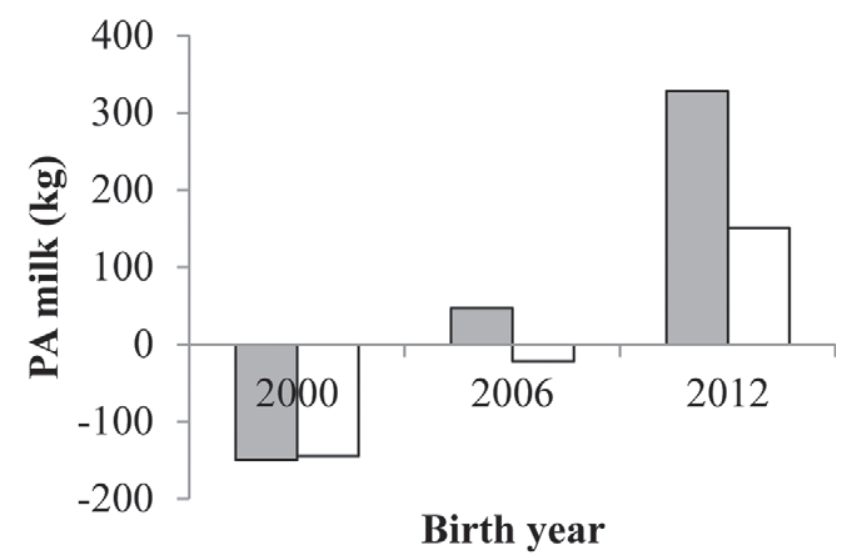

(d)

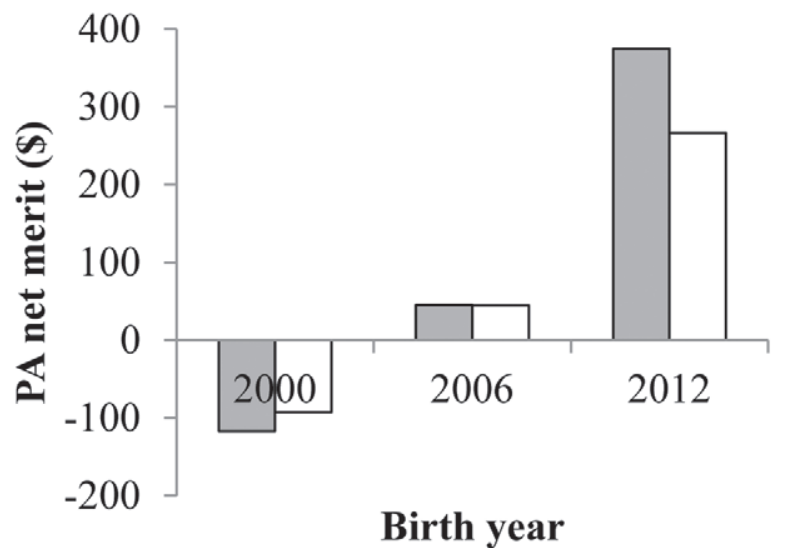

Figure 1. Parent averages (PA) for (a) milk ( $\mathrm{kg}$ ) and (b) net merit (\$) for female Holstein (gray bars) and Jersey (white bars) offspring

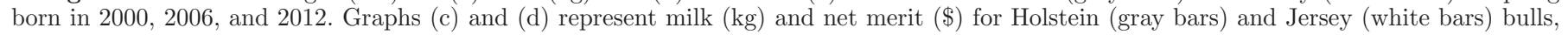
respectively.

between 2006 and 2012 for net merit. This may be due to the fact that selection intensity is much greater for breeders producing males for AI than for herds creating only female replacements (Van Tassell and Van Vleck, 1991). Changes in PA for milk yield in Holsteins were $235 \mathrm{~kg}$ from 2000 to 2006 and $188 \mathrm{~kg}$ between 2006 and 2012, a decrease in gain of $48 \mathrm{~kg}$ between the 2 periods. This decrease may be due to changes in the net merit index over time that have resulted in decreased emphasis on yield traits (57\% in 2000 vs. $35 \%$ at present) and increased emphasis on fitness traits, such as fertility and longevity (14\% in 2000 vs. $33 \%$ at present). Increases of PA for milk yield in Jerseys were $178 \mathrm{~kg}$ from 2000 to 2006 and $184 \mathrm{~kg}$ between 2006 and 2012, an increase of only $7 \mathrm{~kg}$. This may be attributable in part to the preferential utilization of Jersey milk for cheese production; bulls selected using the cheese merit index (Cole et al., 2009) have daughters with high protein yield and reduced milk volume. Between 2000 and 2006, net merit increased by $\$ 167$ for Holsteins, and between 2006 and 2012 it increased by $\$ 220$, a $\$ 53$ increase between these 2 periods. For Jersey female offspring, the increase in net merit was $\$ 40$ higher in the more recent period. A potential source of bias in our data could arise from the fact that very few older cows had lactation records for sires from the 2006 to 2012 period, in contrast to the 2000 to 2006 period. Given that the 2012 genetic evaluation had a different base adjustment value than the 2006 evaluation and that the majority of data from the 2006 genetic evaluation was derived from progeny testing, use of lactation records from the 2012 genetic evaluation allows for a better comparison of the data from these 2 time points, despite the potential for bias.

\section{Herds Using Young Bulls}

The strategy of using young bulls in selection programs may carry a perceived risk to early adopters. To 
Table 4. Usage of young bulls by herd size for Holsteins and Jerseys

\begin{tabular}{|c|c|c|c|c|c|c|}
\hline \multirow{2}{*}{$\begin{array}{l}\text { Breed and } \\
\text { herd size }\end{array}$} & \multicolumn{5}{|c|}{ Herd usage of young bulls (\%) } & \multirow{2}{*}{$\begin{array}{l}\text { Average use of } \\
\text { young bulls (\%) }\end{array}$} \\
\hline & 0 & 1 to 24 & 25 to 49 & 50 to 74 & 75 to 100 & \\
\hline \multicolumn{7}{|l|}{ Holstein } \\
\hline$<30$ & 18.0 & 35.5 & 27.3 & 12.1 & 7.1 & 40.0 \\
\hline 30 to 49 & 11.4 & 38.5 & 29.2 & 14.2 & 6.7 & 31.6 \\
\hline 50 to 99 & 7.8 & 42.1 & 32.3 & 12.2 & 5.6 & 30.6 \\
\hline 100 to 199 & 6.0 & 39.2 & 34.6 & 13.5 & 6.7 & 33.6 \\
\hline 200 to 499 & 4.5 & 34.7 & 32.8 & 18.1 & 9.9 & 38.6 \\
\hline 500 to 999 & 3.6 & 29.0 & 31.2 & 22.6 & 13.6 & 43.8 \\
\hline 1,000 to 1,999 & 3.0 & 28.3 & 28.6 & 22.4 & 17.7 & 45.0 \\
\hline$\geq 2,000$ & 4.0 & 26.1 & 32.9 & 23.9 & 13.1 & 44.5 \\
\hline \multicolumn{7}{|l|}{ Jersey } \\
\hline$<30$ & 32.0 & 32.9 & 18.2 & 9.4 & 7.5 & 16.0 \\
\hline 30 to 49 & 33.5 & 29.7 & 21.0 & 8.8 & 7.0 & 26.9 \\
\hline 50 to 99 & 34.6 & 28.6 & 21.6 & 8.4 & 6.8 & 27.5 \\
\hline 100 to 199 & 36.0 & 25.1 & 22.9 & 10.7 & 5.3 & 33.4 \\
\hline 200 to 499 & 30.3 & 26.5 & 24.2 & 10.1 & 8.9 & 35.8 \\
\hline 500 to 999 & 24.7 & 25.3 & 27.2 & 12.7 & 10.1 & 40.1 \\
\hline 1,000 to 1,999 & 27.2 & 28.1 & 21.0 & 16.7 & 7.0 & 47.4 \\
\hline$\geq 2,000$ & 18.2 & 21.2 & 28.8 & 19.7 & 12.1 & 36.9 \\
\hline
\end{tabular}

estimate the efficacy of the use of young bulls in US dairy herd selection programs, we separated herds by the frequency of their use of young bulls. Herds $(17,519$ Holstein and 4,044 Jersey herds) were categorized into 5 groups: $0 \%$ of young bull usage, 1 to $24 \%$ young bull usage, 25 to $49 \%$ young bull usage, 50 to $74 \%$ young bull usage, and 75 to $100 \%$ young bull usage. Herds were further categorized by the number of cows in milk groupings and by breeding year.

Herds using $0 \%$ young bulls in their selection programs accounted for $9 \%$ of Holstein herds and $33 \%$ of Jersey herds, whereas $7 \%$ of herds (for both Holstein and Jersey) used 75 to $100 \%$ young bulls. When herd size and breeding year were not taken into account, the majority of Holstein (78\%) and Jersey (83\%) herds still used fewer than $50 \%$ of young bulls in their selection programs. When accounting for herd size (Table 4), smaller herds $(<100$ cows in milk) were more likely to use fewer $(<25 \%)$ young bulls than larger herds $(\geq 500$ cows in milk), which were more likely to use more $(\geq 50 \%)$ young bulls in their selection programs. The average use of young bulls was 40.0, 31.6, and $30.6 \%$ for Holstein herd sizes of $<30,30$ to 49 , and 50 to 199 cows, respectively, and $16.0,26.9$, and $27.5 \%$ for Jersey herds; the percentages for herd sizes of 500 to $999,1,000$ to 1,999 , and $\geq 2,000$ cows were $43.8,45.0$, and $44.5 \%$ for Holstein herds and 40.1, 47.4, and 36.9\% for Jersey herds. Larger herds used young bulls more often, which indicates that owners of larger herds are less averse to risk.

Furthermore, herds were divided into regions across the United States, as in Hare et al. (2004). As expected, the northwest region of the United States had the high- est percentage of young bull usage (46.5 for Holsteins and $51.3 \%$ for Jerseys), being where most of the larger herds are located (Table 5). Larger Holstein herds $(\geq 500$ cows in milk) in the northeast and mountain-prairie regions used young bulls more frequently (52 and $49 \%$ of the breedings), compared with 34 and $21 \%$ of the breedings in smaller herds ( $<100$ cows in milk) in the same regions. Larger Jersey herds ( $\geq 500$ cows in milk) in the northwest and southwest regions used young bulls more frequently (56 and $53 \%$ of the breedings), compared with 35 and $32 \%$ of the breedings in smaller herds $(<100$ cows in milk) in the same regions. The southeast and mideast regions had the lowest percentages of young bull usage for Holstein breedings (26.8 and $30.8 \%$, respectively), and the mountain-prairie region for Jersey breedings (26.7\%).

As previously shown with the increased usage of young bulls, herds were more likely to use young bulls in their 2012 selection programs compared with 2007 (Table 6). In 2007, 23\% of Holstein herds used no young bulls, whereas $8 \%$ used $\geq 75 \%$ young bulls in their matings. In 2012, those percentages were 9 and $18 \%$, respectively. Jersey herds showed the same shift, although not as great for the herds using no young bulls. The average use of young bulls for Holstein herds was $28.5,29.5$, and $39.2 \%$ for breeding years 2007 through 2009, respectively, and 24.6, 26.6, and 30.9\% for Jersey herds; the percentages for breeding years 2011 and 2012 were 48.3 and $50.9 \%$ for Holstein herds and 42.7 and $52.4 \%$ for Jersey herds.

To demonstrate the economic effect of the differential use of young bulls, average PTA for milk (Figure 2) and net merit (data not shown) for cows that were bred in 
Table 5. Percentage of young sire usage by region and herd size for Holsteins and Jerseys ${ }^{1}$

\begin{tabular}{|c|c|c|c|c|c|c|c|}
\hline $\begin{array}{l}\text { Breed and } \\
\text { herd size }\end{array}$ & \multicolumn{7}{|c|}{ Region } \\
\hline \multicolumn{8}{|l|}{ Holstein } \\
\hline 30 to 49 & $23.8^{\mathrm{b}}$ & 31.1 & $22.5^{\mathrm{b}}$ & 32.8 & $18.3^{\mathrm{a}}$ & $15.5^{\mathrm{a}}$ & $39.2^{\mathrm{a}}$ \\
\hline 50 to 99 & 26.8 & 30.5 & $22.6^{\mathrm{b}}$ & 32.7 & $28.9^{\mathrm{a}}$ & $17.3^{\mathrm{b}}$ & $65.0^{\mathrm{a}}$ \\
\hline 100 to 199 & 29.1 & 33.2 & $25.5^{\mathrm{b}}$ & 36.0 & $27.2^{\mathrm{b}}$ & 25.6 & $55.1^{\mathrm{b}}$ \\
\hline$\geq 2,000$ & $27.0^{\mathrm{b}}$ & 56.4 & 55.6 & 44.0 & 46.9 & 40.3 & 40.6 \\
\hline \multirow{2}{*}{\multicolumn{8}{|c|}{ Jersey }} \\
\hline & & & & & & & \\
\hline$<30$ & $38.9^{\mathrm{a}}$ & $32.0^{\mathrm{b}}$ & $14.1^{\mathrm{a}}$ & $23.1^{\mathrm{a}}$ & $14.1^{\mathrm{a}}$ & $37.3^{\mathrm{b}}$ & 15.0 \\
\hline 30 to 49 & $24.9^{\mathrm{a}}$ & $27.8^{\mathrm{b}}$ & $21.1^{\mathrm{a}}$ & $26.6^{\mathrm{b}}$ & $11.4^{\mathrm{a}}$ & $27.4^{\mathrm{a}}$ & $68.8^{\mathrm{a}}$ \\
\hline 50 to 99 & $29.7^{\mathrm{b}}$ & $29.2^{\mathrm{b}}$ & $20.4^{\mathrm{a}}$ & $27.6^{\mathrm{b}}$ & $32.2^{\mathrm{a}}$ & $19.5^{\mathrm{a}}$ & $25.5^{\mathrm{a}}$ \\
\hline Total & $32.0^{\mathrm{b}}$ & 35.9 & $26.7^{\mathrm{b}}$ & 33.2 & 51.3 & 44.4 & 31.8 \\
\hline
\end{tabular}

${ }^{1}$ Numbers indicate the percentage of breedings that used young sires $(<4$ yr of age) based on the number of breedings in each subclass, where a $=<10,000$ total breedings and $\mathrm{b}=10,000$ to 100,000 total breedings. The absence of a superscript indicates $>100,000$ total breedings.

2003 through 2012 were calculated, using evaluations from December 2012. In 2003, the PTA of Holstein herds using no young bulls and herds using $>75 \%$ young bulls were similar, with PTA for milk of -199 and -205 $\mathrm{kg}$ and net merit of $-\$ 116$ and $-\$ 119$ (a difference of 6 $\mathrm{kg}$ and $\$ 3$, respectively). By 2012, herds using $>75 \%$ young bulls created offspring that had an advantage for PA of $+52 \mathrm{~kg}$ for milk and $+\$ 58$ net merit compared with herds using no young bulls. Jersey herds using $>$ $75 \%$ young bulls created offspring that had an advantage for PA of $+142 \mathrm{~kg}$ for milk and $+\$ 63$ for net merit compared with herds using no young bulls in 2012 .
All young bulls retained for breeding purposes are now genotyped and can be evaluated on the basis of their genetic composition rather than the performance of their progeny. This, in turn, has decreased the generation interval and increased the rate of genetic gain. Herds using $\geq 75 \%$ young bulls show a higher rate of genetic gain than those using no young bulls, with an increase PTA of $+52 \mathrm{~kg}$ for milk and $+\$ 58$ net merit for Holstein herds and $+142 \mathrm{~kg}$ and $+\$ 63$ for Jersey herds, respectively. Given this economic advantage, increased use of multiple young bulls is recommended in herd breeding programs across the United States.

Table 6. Percentage of Holstein and Jersey herds using young bulls by breeding year

\begin{tabular}{|c|c|c|c|c|c|c|}
\hline \multirow{2}{*}{$\begin{array}{l}\text { Breed and } \\
\text { breeding year }\end{array}$} & \multicolumn{5}{|c|}{ Herd usage of young bulls (\%) } & \multirow{2}{*}{$\begin{array}{l}\text { Average use of } \\
\text { young bulls (\% }\end{array}$} \\
\hline & 0 & 1 to 24 & 25 to 49 & 50 to 74 & 75 to 100 & \\
\hline \multicolumn{7}{|l|}{ Holstein } \\
\hline 2007 & 23.2 & 41.4 & 19.1 & 8.0 & 8.3 & 28.5 \\
\hline 2008 & 19.5 & 42.1 & 21.7 & 8.8 & 7.9 & 29.5 \\
\hline 2009 & 13.0 & 35.6 & 28.2 & 13.7 & 9.5 & 39.2 \\
\hline 2010 & 10.8 & 32.1 & 29.2 & 17.1 & 10.8 & 42.9 \\
\hline 2011 & 9.7 & 29.6 & 26.6 & 19.2 & 14.9 & 48.3 \\
\hline 2012 & 9.1 & 27.4 & 26.0 & 19.5 & 18.0 & 50.9 \\
\hline \multicolumn{7}{|l|}{ Jersey } \\
\hline 2007 & 46.7 & 20.6 & 15.6 & 8.6 & 8.5 & 24.6 \\
\hline 2008 & 46.8 & 21.6 & 15.0 & 7.6 & 9.0 & 26.6 \\
\hline 2009 & 43.3 & 22.8 & 16.3 & 9.4 & 8.2 & 30.9 \\
\hline 2010 & 43.0 & 22.0 & 17.4 & 9.3 & 8.3 & 32.6 \\
\hline 2011 & 37.5 & 17.9 & 20.7 & 13.2 & 10.7 & 42.7 \\
\hline 2012 & 34.6 & 14.5 & 18.5 & 17.4 & 15.0 & 52.4 \\
\hline
\end{tabular}


(a)
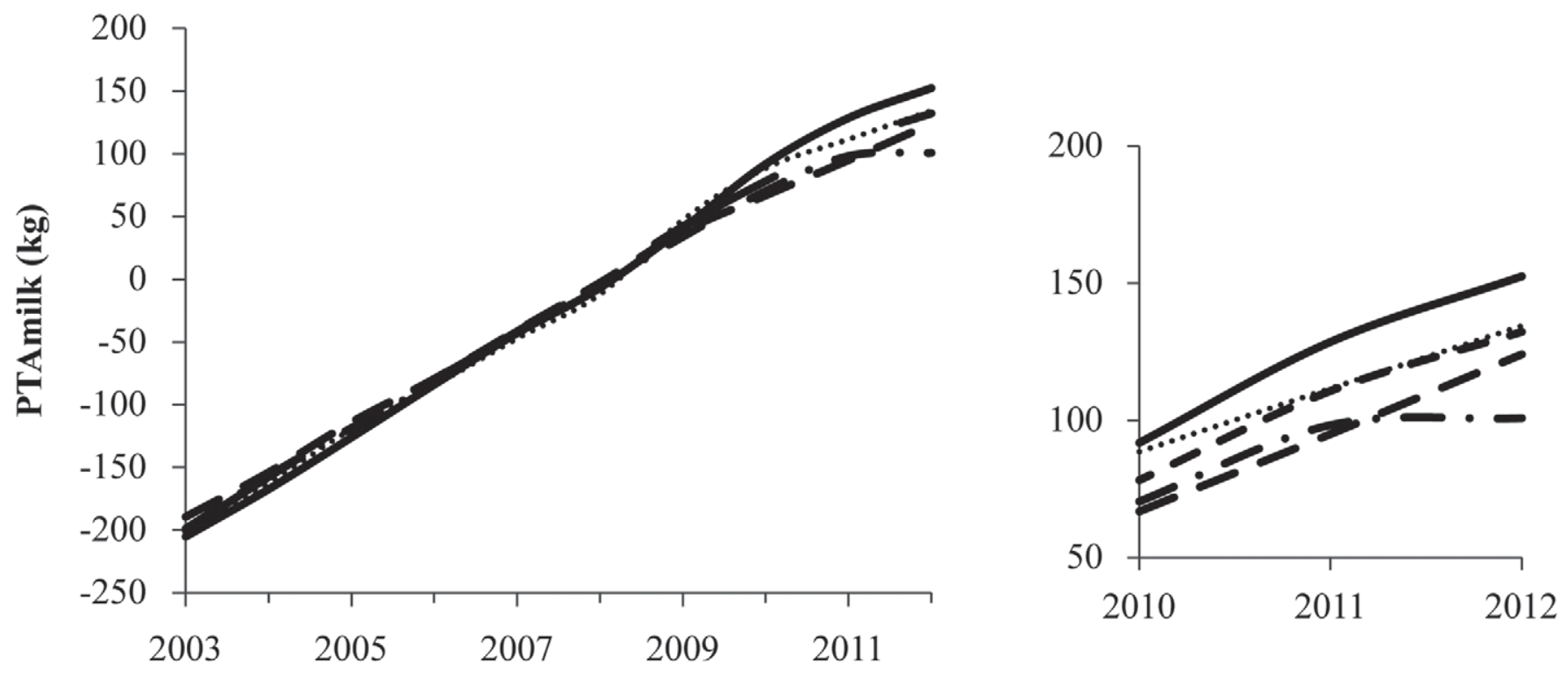

\section{Breeding year}

(b)

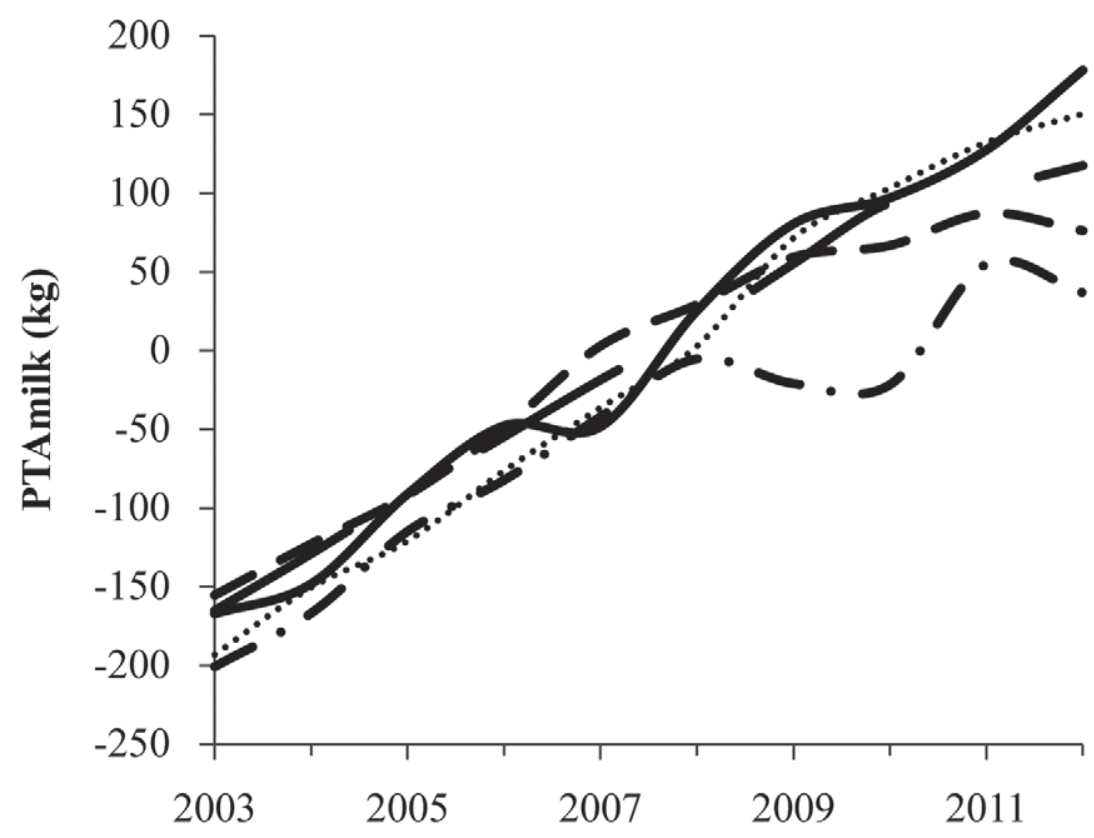

\section{Breeding year}

Figure 2. Predicted transmitting abilities (PTA) for milk (kg) for Holstein (a) and Jersey (b) cows that were bred from 2003 to 2012 , by percentage herd usage of young bulls $(0 \%, \ldots$ - $; 1$ to $24 \%, \ldots-\ldots ; 25$ to $49 \%,---; 50$ to $74 \%, \cdots ;$ and 75 to $100 \%,-)$. The insets in each figure (boxed plots to the right) show finer scale trends for the later data points (specifically for 2010, 2011 and 2012). 


\section{ACKNOWLEDGMENTS}

We acknowledge the cooperation of the Council on Dairy Cattle Breeding (CDCB; Reynoldsburg, OH) in supplying pedigree, performance, and genotypic data. We also thank the CDCB for their review and comments on the manuscript.

\section{REFERENCES}

Cole, J. B., J. L. Hutchison, D. M. Bickhart, and D. J. Null. 2013. Optimal age at first calving for U.S. dairy cattle. Accessed Aug. 28, 2013. http://aipl.arsusda.gov/publish/presentations/ADSA13/ ADSA2013_JLH.pptx.

Cole, J. B., P. M. VanRaden, and Multi-State Project S-1040. 2009 AIPL Research Report NM\$4: Net merit as a measure of lifetime profit: 2010 revision. Accessed Aug. 26, 2013. http://aipl.arsusda. gov/reference/nmcalc.htm.

Hare, E., H. D. Norman, and J. R. Wright. 2004. Duration of herd participation in dairy herd improvement milk recording in the United States. J. Dairy Sci. 87:2743-2747.
Norman, H. D., J. L. Hutchison, and J. B. Cole. 2012. Increased use of young bulls in dairy cattle breeding programs. J. Dairy Sci. 95(Suppl. 2):521. (Abstr.)

Olson, K. M., J. L. Hutchison, P. M. VanRaden, and H. D. Norman. 2011. Changes in the use of young bulls. J. Dairy Sci. 94(E-Suppl. 1):27. (Abstr.)

Schefers, J. M., and K. A. Weigel. 2012. Genomic selection in dairy cattle: Integration of DNA testing into breeding programs. Anim. Front. 2:4-9.

USDA-NASS (National Agricultural Statistics Service). 2013. Prices received for cattle by month-United States. Accessed Nov. 17, 2013. http://www.nass.usda.gov/Charts_and_Maps/ Agricultural_Prices/priceca.asp.

Van Tassell, C. P., and L. D. Van Vleck. 1991. Estimates of genetic selection differentials and generation intervals for four paths of selection. J. Dairy Sci. 74:1078-1086.

Wiggans, G. R., P. M. VanRaden, and T. A. Cooper. 2011. The genomic evaluation system in the United States: Past, present, and future. J. Dairy Sci. 94:3202-3211. 